POLISH POLITICAL SCIENCE

VOL XXXVII 2008

PL ISSN 0208-7375

\title{
CHANGE AS THE SUBJECT OF RESEARCH IN THE INTERNATIONAL RELATIONS SCIENCE
}

\author{
by Teresa Łoś-Nowak
}

1. How, by what methods should one examine what is significant in the modern, rapidly changing world, in order to make a theory tool good enough not only to explain, but also to expose changes in modern, rapidly changing world?

2. What are the symbols and carriers of changes occurring in the area of international relations, in the international system?

3. How to define these relevancies?

Questions asked above are in fact questions about theoretical identity, explanative efficiency and scope of researches in the international relations science, undertaken attempts of answering them decide on particular complexity of the subject of researches, controversies around subjective scope of researches and research methods. Starting from the first serious, inter-paradigmatic debate at the turn of nineteen fifties and sixties, conducted by representatives of the realistic trend and new behavioural approach to the last debate from nineteen eighties and nineties, there has been lasting discussion on ontological and epistemological problems of the international relations science'. However, it does not discourage researchers from continuing

1 K.J. Holsti, The Dividing Discipline. Hegemony and Diversity in International Theory. Boston 1965; J.S. Nye, Jr. Studying World Politics, [in:] Journeys through World Politics. Autobiographical Reflections of Thirty-fourth Academic Travel, J. Krazel, J.N. Rosenau (eds.), Lexington Books 1989, p. 199-212; E. Adler, Cognitive Evolution: A Dynamic Approach for the Study of International Relations and Their Progress, [in:] E. Adler, B. Crawford, Progression in Post-War International Relations, New York 1991, pp. 43-89. 
careful and considerable reflection on the condition of discipline and its place in the Pantheon of Science, and for sure it does not discourage them from deepening theoretical discourse on explanative efficiency of various theoretical approaches and their methodological correctness in the process of getting to know, as well as explaining world complexity at the turn of the 20th and 21 st century and new gauntlets thrown down by the 21 st century.

Like in every scientific discipline, and for sure in such one, whose research field undergoes unprecedented dynamics of changes both when it is about the number of participants of international relations, and their diverse political and legal status, potential and power of influence. It actuates the scale of interaction between them, creates new forms and kinds of international connections, releases phenomena unknown in the past.

Undoubtedly, new theoretical approaches destroy classical and "correct" analytical models, introduce into discussion inter-subjective elements of interpretation of new phenomena and processes occurring in the international environment, which hampers their understanding, raises new dangers and reduces chances of modern world development. And this cannot find itself in an intellectual trap of "postmodernity", in which "old" principles of explaining international phenomena and processes, crisis of the state, derogation of international law, morality, etc., values appear not to be fully efficient, there are no new values or common consent to their implementation. Modern researchers, especially representatives of the rich and internally diverse post-positivist trend, distance themselves from knowledge about international relations acquired by following generations, contesting especially their methodological achievements and contribution to theoretical researches. Rejecting it as useless for understanding the modern, globalised world and depth of changes, which occurred in it, they propose models allowing for total interpretative freedom of researcher, when it is about ontological level of international relations, specific scientific voluntarism, lack of restrictions and precision in using concepts present in the process of getting to know the international reality. As a result, specific scientific credo of many modern researches has become quite common, that previous scientific achievements about reality fulfilling the condition of authenticity and methodology applied in researches are too limited and unreliable to be treated seriously. Just postpostmodernist epoch dominating in literature, architecture, music, but also in social sciences, mainly philosophy and sociology with its manifesto "nothing is written", is supposed to decide on a turning point in the international relations theory.

The initial point of post-modernist manifesto and constructionism, questioning canons of neorealism and neoliberalism and turning away from positivist understanding of science and its functions, would be accepting several substantial theses about the impossibility of objectivisation of research results, mythologizing the 
empiricism by traditionalists, rationality of activities of international relations participants, cultural determinants in examining world politics, etc., in the world, where everything changes faster than it becomes. Such a manifesto by its very nature provokes questions about research workshop of representatives of post-positivist trend, efficiency of explanative, prognostic mechanisms and others, about understanding science. $^{2}$

Paradoxically, in the international relations science, contrary to many experimental, natural sciences, where experiment plays the basic role, accumulation of knowledge about the world of political phenomena, about the phenomenon of state and its exceptionality amongst other subjects of international relations, a-hierarchicity of the international system and polyarchy of the international environment are confronted with variety of applied methods, which causes that international reality or its fragments become actually the subject of a dispute. An axis around which the discussion concentrates is methodological variety, so big, that it hampers, or sometimes makes impossible its cognition, describing, understanding, prospecting. Disputes over which of the commonly applied general or detailed methods in social sciences should be considered as the most appropriate are a burden to the image of discipline, particularly its status of the system of other social sciences. Y.H. Ferguson and R.W. Mansbach do not hide their disappointment with level and efficiency of discussion on this exact topic. In the dissertation The State, Conceptional Chaos and the Future of International Theory they write critically, that "science, which is not able to define its subject of researches accepted by all its representatives, undermines its raison d'etre". As a result of conceptional chaos in it, it reminds rather a "flea market", "plundering in history", than a "serious academic discipline." 3 A critical assessment, but at the same time very disputable. The mentioned researchers claim unambiguously that without a clearly determined subject of researches and methods allocated to this actual discipline, it does not have a right to legitimise its academic status. This is an attitude opting for applying classical "Kuhn's" model of science in the international relations science. Luckily, a lot has changed in this area, the international relations science and its theoretical base have undergone great enrichment. Obviously, it would be a sign of vanity, if we said that we had the phase of ordered, unambiguously simple interpretation of phenomena and processes occurring "before observers eyes" almost at every moment accepted by all researchers, behind us. We are rather in the next phase of scientific evolution, whose richness and methodological variety

2 C. Enloe, M. Zalewski, Questions about Identity in International Relations, [in:] K. Booth and S. Smith, International Relations Theory Today, Cambridge 1995, pp. 278-305.

3 Y.H. Ferguson, R.W. Masbach, The State, Conceptional Chaos and the Future of International Theory, Denver 1989, p. 82, 83. 
rather "blur" the image of the world of politicians, actors, causative power of their behaviours, etc., than brighten it, complicating epistemological layer of the international relations science. This all demonstrates, however, the power of scientific discourse and its need.

Awareness of weaknesses, which are a burden to this young discipline does not mean, though, depreciating its scientific achievements, perceiving methodological discussions lasting for decades as a sign of complete infirmity and disbelief in sense and chances for theorising in this area. Contrary, awareness of difficulties which pile up in theoretical discourse mobilises to searching for research methods most reflecting the specificity of the subject, its multilayered dimension and dynamic character. There arises from it knowledge of full value about changing the world of international politics, changeable rules regulating international environment, evolution of the international system, its structures, multilayered management mechanisms and actors playing their roles in it. It concerns both old actors, which are states, and new, such as i.e. transnational organisations.

However, something causes that difficulties in determining clear and unambiguous research paradigms as knowledge are being acquired, they pile up instead of weakening, and the environment of researchers speaks a more and more hermetic language, often mutually questioned. This provides those, who claim that it is unable or not eager to mutually understand each other, with "breeding-ground". This state of conceptional chaos refers particularly to the last debate described as post-positivist. As John A. Vasquez notices "Post-positivism caused that researches of the world politics were in serious crisis". This state pleases those, for whom positivist achievement of the international relations science is not too intellectually attractive, rarely described as primitive, and upsets those, for whom intellectual summit of postpositivist achievements is hardly clear and does not serve explaining. ${ }^{4}$

In fascination with meta-language and meta-world, as well as criticism of previous achievements of the international relations, representatives of post-positivist theories seem to see a chance for building real theory in cognitivism, semiotics, hermeneutical approach to interpretation and understanding of the world. They do not appreciate, though, researches of experimental kind, sceptically approach serious analyses framed normatively, do not comply with discipline typical for theoretical researches. Researchers of this trend - besides, very diverse inside - are characterised by scientific relativism and advanced subjectivism, bordering sometimes with purely idealistic attitudes, which assume that international relations are shaped only by language, ideas and concepts. One may even risk the statement, to some extent

${ }^{4}$ J.A. Vasquez, Post-positivism and the Future of International Relations Theory, [in:] K. Booth, S. Smith, International Relations Theory Today, Cambridge 1995, p. 234. 
a priori, that as much as the third inter-paradigmatic debate can be perceived as a critical point in researches on the world politics and international relations, it did not become a turning point, from which the process of its reconstruction could start - so serious, that one could talk about a breakthrough in building the international relations theory. Contrary, one can consider if achievements of the last, fourth interparadigmatic debate are not used by representatives and followers of more traditional approach to the theory of international relations as the attempt of complete discredit of achievements of the first and second debate and ignore it completely, to the detriment of theory in the international relations science and researchers themselves.

Discussion between representatives of broadly understood traditional approach and new generation of researchers, fascinated with modern philosophy lasting since the turn of nineteen eighties and nineties, lets us hope, though, that both the first ones and post-positivists, especially post-modernists and representatives of the constructionist trend, discussing between each other, not only "with each other", will deepen the knowledge about the world of international politics, phenomenon of post-modernity and its specificity. Only in this way will they be able to get to know and understand each other better. One may hope that science and theory function a little like a self-regulating mechanism, which will enable communication of representatives of various schools, various traditions and various attitudes to the world, also those seeing the source of its better cognition and description in semiotics, in examining categories important in the international relations theory such as state or sovereignty metaphorically, as symbols of determined ideas, values, power of knowledge. ${ }^{5}$

\section{THEORY OF INTERNATIONAL RELATIONS: ITS VARIOUS VISIONS, VARIOUS UNDERSTANDING, VARIOUS FUNCTIONS}

I will start from emphasising an apparently banal statement that the centre of gravity in a discussion on theory and research directions in the international relations science is in multiple and variety of schools and research trends, which differ in understanding theory, its functions and understanding its essence ${ }^{6}$. For one group theory is first of all methodology, in which dominate techniques facilitating (enabling)

${ }^{5}$ C. Maj, International Stability: What Can We learn from Systems Metaphors and Analogies, "Working Papers" 1993, No. 3. Center For Peace and Conflict Research, Copenhagen 1993.

${ }^{6}$ More about this topic, M.V. Kauppi, P.R. Viotti, International Relations. Theory. Realism, Pluralism, Globalism, New York 1987. 
understanding and explaining phenomena and processes occurring in the international system, premises of its evolution, new challenges and chances, which they bear, but also dangers they may cause ${ }^{7}$. These are representatives of the neorealistic trend, still present and cognitively attractive. For representatives of quite heterogeneous post-positivist trend, theory is first of all to serve understanding of the world, where knowledge about it, experience, believed ideas and values are useful. The objective is interpretation of reality created by a researcher, they interpret the reality, a concrete problem, phenomenon, process. Knowledge about them is always subjective narration of a researcher. Theory - as R. Cox writes - one of prominent representatives of the critical trend in the lasting discussion - "is always for somebody and serves some purpose", that means it is a highly subjective process of cognition. It is always burdened with a "sin" of relativism.

For the extensive group of representatives of the post-positivist trend, such as e.g. R.K. Ashley, M. Schapiro, R.B.J. Walker, D.J. Georgie, B. Klein, the task of researcher - the international relations theoretician - is not discovering and explaining the international reality, mechanisms ruling behaviours of international relations participants, valid regulations, but its deconstruction, exposing imperfection and unfairness. Explanation is a process, in which the most important component is intesubjective awareness of a researcher, its knowledge about the world, determined by professed system of values, ideas, burdened with experiences. Reality does not exist as objective state.

In the postmodernist convention, "researchers are deconstructionists, describing theories by the name of "narration" or "meta-narration", and what they achieve as the effect of a mental process is contaminated by their subjective point of view, professed ideas and system of values, experiences, phobias or even prejudices ${ }^{9}$. In this approach the world is a specific "product" of researchers and the epoch in which they live.

"Achievements" of the international relations science are created also by researchers, for whom "theory" is the process, whose objective and main message is understanding the world, creating mechanisms of explaining phenomena and processes present in it, determining possible paths of its development, searching for objective factors of changes occurring in the international system, its structure, in

7 Representatives of the positivist methodology.

8 R. Cox, Social forces, States, and World Orders: Beyond International Relations Theory "Millennium" 1981, Vol. 10, No. 2, p. 128.

9 R. Jackson, G. Sørensen, Wprowadzenie do teorii stosunków międzynarodowych. Teorie i kierunki badawcze, Kracow 2006, p. 268. 
the field of international relations and rights valid in $\mathrm{it}^{10}$. So for neorealistic and behavioural school in the international relations science the most important task of theory is provision of possibly objective research tools, bringing closer the reality in its complex shape, getting to know it and understand it better, not its creation or intersubjective interpretation. In science it is manly about "explaining mechanisms of functioning of determined regularities or rules of behaviour of international relations participants and its essence", K. Waltz" says, or "hypothetical abstract presentation of examined phenomenon or reality", as Torbjörn L. Knutzen claims. So theorising is a "mental process, whose objective is understanding and explaining its complexity"12. "good" theory is a theory coming true in reality, submitting to experience ${ }^{13}$.

Misunderstandings, which have been accumulating for years among the theory of international relations, result from different understanding of the subject of cognition by those, who are occupied with the international relations science. It causes - as it was suggested above - division for the followers of theory whose essence is explaining (explanation) and those, who search for its essence in constitutive possibilities (constitutive approach), in interpretative power of institutions created by people, actors participating in the world of politics, social and political systems, which they create by means of rich arsenal of thoughts, ideas, values, experiences ${ }^{14}$. It gives images of an intersubjective, narrative world, sceptical towards all attempts of explaining processes occurring in it, building objective principles, possibilities of their verification, real beings. They do not have any meaning without intellectual baggage of a researcher, who gives them content relevant to time and place. Scepticism towards positivist methods exposed in classical paradigms results from conviction that the world of social (nation), political (state, sovereignty), cultural beings cannot be described by means of so called objective laws or principles, as positivists or behaviourists claim. Their verification in time and space is simply impossible, because it is

10 I omit knowingly discussions on criteria, which should be fulfilled by a good theory. More about this topic: J.A. Vasquez, The Post-Positive Debate. Reconstructing..., [in:] M.V. Kauppi, R. Viotti, International Relations. Theory. Realism.., p. 329.

11 K.N. Waltz, Theory of International Politics, Berkeley 1979, p. 2., see also: J. Kukułka, Problemy teorii stosunków międzynarodowych, Warsaw 1978, p. 57. About this subject also, Ch. Reus-Smith, Constructivism, [in:] Theories of International relations, S. Burchill (ed.), New York, 2003, p. 209.

12 T.N. Knutsen, op.cit., p. 1.

13 K.N. Waltz, Theory of International Politics, California, Berkeley 1979, p. 5.

${ }^{14}$ S. Smith, The Self-Image of Discipline: genealogy of International Relations Theory, [in:] International Relations Theory,S. Smith, K. Booth (eds.), Cambridge 1995, pp. 26-27. 
always a different world, different people, different ideas form it, different objectives are important for them ${ }^{15}$.

The existence of this theoretical dissonance of schools does not facilitate the process of building the identity of discipline, its image of "hardened" science about recognised research methods and unquestionable achievements. Meanwhile, both approaches are important and complementary with regard to each other. The essence of science is examining real beings existing in the real world, their construction, mechanisms of functioning, searching for the specificity or similarities in behaviours, deciding on a history of countries, nations, individuals. This is a specific minimum program of scientificity, a maximum program is building theoretical generalisations, regularities, theses verified in determined conditions or their falseness in other terms, etc.

As S. Burchill rightly emphasises, building a theory existing next to the real world is both an artificial and little credible procedure, if it is about the final effect, that is the credibility of results, similarly like excessive fascination which universal laws and truths, valid regardless of historical time and place of event, what is forced by neorealists. These two worlds should not be artificially separated. Theory takes its vital force from what surrounds a researcher, that is from the real world of politics, where are states, nations, striving for domination, but also for peace and welfare, respecting cultural and social differences, as well as other fascinating subjects and objects of cognition, striving for changing old order, introducing new values and ideas. Only in this way one can explain the complexity of such phenomena as state and its position in a system, power, security, but also outdo this reality, moderate it $^{16}$. When separating a subject from an object of cognition it is easy to fall into manners of post-positivist methodology dominating in the international relations science from the end of the nineteen eighties, which exposed it to an objection of mannerism, excessive sophistry and semiotics. So it is worth asking again an apparently naive question, if thought has to have a material base, and each methodologically correct analysis of international relations should start from it or not, if thinking about thinking only by means of a language of metaphors, Plato's world of ideas, values, cultural and political determinants would not lead us to whata great Polish philosopher calls "horror metaphysicus"

These theories cannot and should not close or limit their abilities to explain and foresee. Their great potential is also in possibilities of theoretical humanistic reflection about features and character of the world politics, its ethical and human dimen-

15 J.E. Dougherty, R.L. Pfaltzgraff, Jr., Contending Theories of International Relations. A Comprehensive Survey, New York 2001, pp. 22-28.

${ }_{16}$ Theories of International Relations, S. Burchill (ed.), New York 2003, pp. 2-3.

17 L. Kołakowski, Horror Metaphysicus, Warsaw 1990. 
sion $^{18}$. Both theoretical dimensions, this closing itself in critical vision of examined reality and this reflective, concentrated on values, humanism and ethics, are important in the process of cognition. Overestimating, underestimating or, which is the worst in science, disrespect are harmful. Methodology following mental schemes widespread from ages etc., when applied to the modernity will generate untrue, superficial knowledge and ineffective diagnoses. It will not be a career and stimulator of changes and progress in the world. But scholars "rather than interpret the world" should care more about finding ways to its changes, to change of social, political life terms, removing limitations, which petrify inequalities, unfairness, lack of freedom, etc. This credo, important for theoreticians of international relations, with decidedly liberal intellectual background, starting from the first classical paradigm, called idealistic (often utopian idealism), finishing on postmodernist and post-positivist paradigms, was in opposition to realistic school in the international relations science. As much as Wilson's idealism and in later period various varieties of neoliberal paradigms accent the belief in the power of human reason, in conviction about opportunities of building a better world using knowledge acquired for years, realism and neorealism in their theoretical deliberations about the nature of the world of politics expose timeless values and rules of proceedings in the international relations, universal priorities, by which people in power are guided in their foreign policy, regardless of time and place where they function, neutral and objective laws. Methods dominating in the neorealistic and partly modernist trends seem to overestimate the statistic dimension of the world, durability of rules regulating it, domination of these values, principles and rules regulating international relations for centuries.

The belief in progress, in the possibility of reduction of unfairness and social inequalities, in abetter, fairer world - inscribed in the philosophy of broadly understood neoliberal trend - was supposed to mean greater openness and ability to introduce changes in the international relations and world politics, while pessimistic and doubting representatives of the H. Morgenth's realistic and K. Waltz or R. Gilpin's neorealistic trends are genetically incapable of building such an image of the world, where progress is possible, just like social emancipation, respecting human rights, internal and external safety, as well as other similar values. The general charge from the side of representatives of the post-positivist trend, especially postmodernists, deconstructionists and structuralists presented in the fourth debate is included in this - neorealists "do not deal" with the phenomenon of "change" in the international relations and the idea of progress, social development. For those the first phenomenon of "change" as the object of research is a key to getting to know the modern world, the scale of importance of problems generated by it, the reasons, for which it

18 S. Smith, op.cit., p. 27. 
is changing, how actors of international relations and functions performed traditionally by them are changing. Realism is more an offer of decidedly more static world, governed by established laws, with states having a dominating position in the international system and dominating rules of proceeding, shaped by generations.

It seems that regardless of differences in understanding the role of science, the issue of methodology of researches and research techniques, entrenching oneself on own positions is deceptive and scientifically not far-reaching. Both classical paradigms and postmodernism or post-positivism can bring a lot to the discussion on the theory of international relations. An a ssumption of a researcher, that without getting to know and understanding the role of ideas and metaphors, ideology in acting and transforming the really existing beings one cannot get to know or understand the sense of their change, cannot mean granting them the role of a basic factor, neither all the more initial. "...idea, although secondary towards ontologically basic fact of power, is also initial towards a phenomenon - in the course of evolution more and more complex - which is politics"19, including the world of politics, actors and their attitudes towards problems of the modern world and other variables. Surely in the 21st century there is a need of complex thinking, exceeding individual cases in the direction of finding problems conditioning each other. Because the whole space, in which a researcher is, the language of communication, system of values change rapidly, which causes that it is enriched by the world of symbols and metaphors, but also on the other hand there is a need of careful listening to what representatives of various traditions and schools of getting to know the world, including realists, are saying.

Summing up, one can accept that the debate between fundamentalists and antifundamentalists in theory was showing that all binary generalisation is wrong and does not push science ahead. "Theories matter not only in themselves, but also to a significant measure they serve as a signpost for practice"20

\section{DO THEORIES IN THE INTERNATIONAL RELATIONS SCIENCE DIFFER FROM EACH OTHER AND BY WHAT?}

Firstly, participants of the post-positivist debate concentrate their intellectual effort first of all on recognising the power of knowledge in getting to know and explaining international reality, on the emancipating role of knowledge, on its ethical-moral message and functions, which will make more efficient identification of

19 L. Szczegóła, Polityka, jako instytucjonalizacja idei, [in:] Metafory Polityki, B. Karczmarek (ed.), Warsaw 2001, p. 160.

20 R. Jackson, G. Sørensen, op.cit., p. XVI. 
new factors and causative powers of changes in the international system and world politics possible R. Cox e.g. exposes the emancipating function of knowledge, provided by researchers in order to make it serve providing with social progress, liquidation of social inequalities and discrimination, not their petrification ${ }^{21}$. Secondly, they differ from each other (although to a lesser degree), when it is about the ontological level of international relations, more strictly its scope. For modern researchers of generation - R. Cox, S. Smith, A. Gidens, Linklater - international reality, which should be examined, is a "discursive" phenomenon, not so obvious, as neorealists emphasise - given once for all ${ }^{22}$.

A weak point of the school of traditionalists are mechanisms of identification of international relations participants and assessment of their importance in the world politics. Not necessarily and not always states are and can be them. There are also differently asked questions e.g. about the nature of modern state, about other forms of organising communities, not trammelled by 5 signs of monopolisation and petrification of a special (exceptional) role and position of a state in the international environment, if one should examine all the time the same actors, but in different costumes, or rather make attempts to discover their unknown or disrespected features, at last limitations, which seem to determine their end. So they are nagged by the function of the knowledge about the world, its subjective and objective structure, challenges, needs, dangers, importance of the international relations level, premises of the correctness of the international system functioning. It creates the surrounding world, its quality, dynamics of development, making it possible to get to know by "eyes" of a researcher, entangled in problems they want to solve. So by the fact that researcher cannot be "in" examined phenomenon or problem, the result of their researches is "contaminated" by knowledge acquired about it, the held point of view, norms, historical experience, other similar factors - the result of their researches is always subjective, is "their" assessment, their way of explanation, understanding e.g. premises of building the Westphalia or Versal order. Such an attitude signalises the epistemological assumption that there does not exist an objective world, objective truths and laws.

Next difference concerns the level of analysis and accepted criteria of assessing. Admittedly, the neorealistic trend left its classical prototype, orienting its interest towards the level of international system or orientation towards state business as exclusive causative power of its behaviours, however, this is still a system of states and

${ }^{21}$ R. Cox, Towards a Post-Hegemonic Conceptualization of World Order: Reflection on Relevance of Ibn Khaldun, [in:] E.O. Czempiel, J.N. Rosenau, Governance Without Government: Order and Change in World Politics, Cambridge 1992, pp. 132-133.

${ }^{22}$ Broadly, [in:] J.N. Rosenau, E.O. Czempiel, Governance Without Government: Order and Change in World Politics, Cambridge 1992. 
relations inter states, too simplified these days. Here I have on my mind both attributiveness of state actors and their limited ability to prefer deep changes in the international system, the will of legitimisation of a more and more extensive group of non-state actors to participate in the process of management of the mentioned international disorder, to set free from limitations, which are imposed by the system perceived as a symbol of distribution of power in the international environment, serving by that the consolidation of the existing inequalities, not their change. For the critical school they constitute the sense of being and developing each science, each real scientific discipline.

In criticism, to which representatives of the post-positivist trend subjected the broadly understood neorealistic approach, basically the most important and the most accurate point of reference seems to be its relative stability. It stays in an intellectual offer, which is preferred by the followers of traditional understanding of theory, particularly in respect of an subject, object, as well as research methods. As a result they define neorealism as an ahistorical, regressive approach, unable to indicate new phenomena and processes occurring in the world, new actors, motivations of their actions, causative powers of changes and such decisions which would prefer social and culturalcivilisation progress, broaden the scale of freedom of individuals and equality in the international system, new forms of organisation of the international system and others. So between the positivist and modernist school there is a debate over the method and role of science or, as the latter emphasises sometimes, over the "power" of knowledge in building a better world. Those first ones postulate the pattern of objective, verified and tested science. The latter question the possibility of building objective science in a matter very dynamic from its essence, able to be empirically verified. ${ }^{23}$ They indicate by that, not without right, a particular complexity and dynamics of changes which occur in the field of international relations, with participation of the world of politics stage equally rapidly becoming crowded by new actors. The "whirling world" turns around faster than 50 or 20 years ago, generating changes that may cause that it will stop for longer time in majestic silence. So we have a situation, in which on the one side researchers "entrenched" on their positions, exposing the possibility and need of building new research instruments, allowing for an objective (that is scientific), without historical determinants, subjective interpretations of the world, freedom from ideologies, politically neutral, experiences or prejudices, on the other side those, who a priori assume that it is impossible, that in social science, to which undoubtedly this discipline belongs, history of ideas, values, moralities seem to be the most important. Only when using them one can change the world, release social powers able to change the world.

${ }^{23}$ R. Cox, Social Forces. States and World Orders. Blond International Relations Theory "Millenium" 1981, Vol. 10, No. 2, p. 128. 
Objection raised the most often to representatives of the classical trend (that is broadly understood realism, but also institutional neoliberalism), may be reduced to that it runs out of the theoretical base allowing to catch qualitative changes in the international system, discover others like built on power relations in the type of inter states dominating in the international relations, or at least corrections of them. Certainly, this is a strongly distorted image of the traditional trend, including neorealism and institutional liberalism. Nevertheless, such a "pigeonholing" of achievements of this trend representatives causes, that it bears signs of stability, fatality of destiny, this persistence in a state not "good" for everybody, an international system, which is favourable for strong ones and plunges weaker ones, etc. On the other hand we have representatives of the post-positivism, with their tendency to treat science as a tool enabling "understanding" of the world and interpreting a concrete issue, reaching for achievements of knowledge, which are given by ethics, universal values, law, justice, social liberation, humanitarism. Problems arise when there appears the need of indicating subjects able to efficiently move these values in the real world, in which states "settle" their selfish businesses, and alternative forms of organisation of political societies are more an idea than a real being able to act. Cases of wars for Kosovo or Ossetia and Abkhazia clearly indicate what is important in the international politics and foreign policy of the state. As a result, post-positivists describe these traditional approaches as ahistorical, regressive, and their representatives as unable to indicate phenomena and processes occurring in the world, new actors and their motivations in made decisions in the international politics and other causative powers, which would prefer social and cultural-civilisation progress, broaden the scale of freedom of individuals and equality in the international relations system, introduce new forms of organisation of the international community, greater loyalty and solidarity with those excluded from the possibility of using achievements of civilisation..$^{24}$ Due to that, in the currently lasting discussion on building the international relations theory there is a cacophony of visions, paradigms, schools, models, often internally contradictory, out of focus, presented by the language of metaphors and figures of speech. The latter is not an evil itself. "Allow for spatial, panoramic capturing phenomena, for construction of their models, just by putting on each other and connecting in one vision the reality of many of its metaphors." ${ }^{25}$ The essence of researches is, though, in this, that a research process and deep cognition do not finish on constructing sometimes unusually accurate metaphors.

${ }_{24}$ Z. Bauman, Życie na przemiał, Kracow 2004, K.J. Holsti, The State, War and the State of War, Cambridge 1996.

${ }^{25}$ From the introduction by B. Kaczmarek to Metafory Polityki, vol. 2, Warsaw 2003, p. 9. 
It would seem that the reflective approach, proposed by a new generation of researchers, a generation brought up on the cult of modern philosophy, philosophy of science, theory of cognition, phenomenology and often semiotics have propositions able to really revolutionise achievements of the international relations science, constitute a specific breakthrough in building the international relations theory. Meanwhile, its accurate analysis allows - with great dose of probability - to say that it introduces to researches a lot of intellectual conceptual chaos, a lot of ambiguities, preserves aversion to this scientific discipline, framing it by rigor of thinking, acting according to the accepted criteria. Above all, though, there dominates a specific cult of idea on it, philosophical fascinations with the nature of good, law, ethics, morality, etc. Its representatives also distance themselves consciously - sometimes ostentatiously - from material resources, making powerful (or weak) "players" in the world politics from participants of the international relations. In this moment it is worth answering the question, if such an "alienated", over-intellectualised approach really answers the demand for explaining, which will not be so naive as "Wilson's" idealism, neither so simple as neorealism, nor so metaphysical as structural realism of K. Waltz. It does not seem like that. Maybe at the most they seem to differently ask the research question: "from what to how." 26

Surely, the restoration of social and cultural threads in building research models in the international relations and paying greater attention to not material and sometimes being in an intellectual opposition to realism premises of behaviours of states and other participants of the international relations, disturbs the ordered model of neorealistic analysis. For its representatives the international relations are still the area of "recurrences and repetitions", business of state is still, if not the most important, significant in the process of building the foreign policy, human nature is invariable in its essence, striving for surviving and building position in the international system determines the essence of politics. As a result of such an approach one makes a charge of the lack of awareness of that world is an unusually dynamic matter, researchers, instead of identifying these changes, petrify those found, which is not fully right or true. Such an awareness is possessed by neorealists with R. Gilpin at the top. He actually made the category of "change" the central point of researches in the dissertation War and Change in World Politics. More significant in the process of cognition is question how to unmask these changes, face them and introduce into the international system, guaranteeing at the same time its dynamic character. Mean-

${ }^{26}$ More about the subject of post-positivist debate and its contribution to development of the international relations science J.P. Vasquez writes in the article The Post-positivist debate. Reconstructing Scientific Enquiry and International Relations Theory Today, [in:] K. Booth, S. Smith, op.cit., pp. 241-263. 
while - as above-mentioned R. Gilpin wrote - "Change is a fundamental research problem in the modern world." ${ }^{27}$ It is also permanently inscribed in the world politics and everything what surrounds us.

Criticism, with which representatives of neorealism and its derivatives meet, concerns two issues; firstly, eagerness to consider that changes occur generally by force, and secondly, recurrence of the process of building the international system and mechanisms of its durability. Usually such a "backbone" of system was superpower, having at its disposal surplus of potential needed to guarantee its relative stability (sometimes described as leader, sometimes as hegemon). Currently, such a simple mechanism is not possible to be moved to the international environment, decidedly more polycentric and polyarchic than 60 years ago. ${ }^{28}$ As a sign of intellectual weakness one evokes complete impossibility of building clear international order in the post-Westphalia or late Westphalia world, collision of universalisation of order with tendencies to regionalisation, various models of governance being a symbol of a new approach to forms and methods of management in the multidimensional world and multilayered international system. ${ }^{29}$ However, it is far in this process to the international order legitimised by the international community. Reinterpretation of the "old" was not an easy procedure in the past and today still it is not. Traditional, vertical structure of the international order was questioned, new "players" appeared, globalisation leaves its stamp everywhere, not only perception of security changed, but also of its danger, process of regional and over-regional integration intensified. Above all, however, - as rightly R. Kuzniar emphasises - "lack of new "hard" treaty base ("turning point") for the new international order, as it was in the past..." ${ }^{30}$ Its projection is difficult, but not impossible. Science can also play its great, historical mission in this process. To this, as in each scientific discipline, one needs clear concepts, clear qualitative, assessing criteria of importance of changes, their results, and first of all academic discipline. They help in logical and coherent, but also critical thinking. By that they help not only to model the world in our minds, but

27 R. Gilpin, War and change...

${ }_{28}$ T. Łoś-Nowak, Paradygmat realistyczny - projekcie porządku międzynarodowego w XXI wieku, [in:] Porządek międzynarodowy u progu XXI wieku, R. Kuźniar (ed.), Warszawa 2005, pp. 21-59. In the mentioned work Reader will find a lot of interesting considerations about possible visions of the international order, premises of intellectual offers and ideological principles.

29 A. Polus, Governance w stosunkach międzynarodowych, [in:] Regionalizacja w stosunkach międzynarodowych. Aspekty polityczno-gospodarcze, collective work under the edition of. E. Stadtmüller, Toruń 2008, pp. 39-59.

${ }^{30}$ R. Kuźniar, op.cit., p. 8 (from the Introduction to the work). 
also to change it or at least indicate directions of changes and their dynamics in real order of things and - what is incredibly important - their consequences.

\section{CHANGE AS RESEARCH PHENOMENON OR POLITICAL METAPHOR?}

"Change", "changeability" - an ambiguous term and difficult to be unambiguously defined, not only on the ground of international relations science, maybe this metaphor of all incomprehensible processes and phenomena from the world of politics (including international and foreign), whose objective is getting to know causative power of these changes, their dynamics, directions and consequences. However, it always symbolises movement, as a result of which there always becomes something new, unknown, there appears a new participant of the international relations, the international system structure changes, there appear new institutions, new rules of proceedings, new systems of valuing, etc.

In this state of matter there arises a question, if dominating in applied sciences Kuhn's model of science, accepted in the positivist approach to researches through trends commonly recognised as traditional, so also realism and neorealism, is not a too tight theoretical corset, in order to satisfy the most important functions of the international relations science - to make it not only explain the functioning of significant phenomena of the modern world, as power and might, sovereignty versus globalisation and interdependence, security in its broad context and others, but first of all, to provide an essential tool to re-discover causative power of changes in the international system and their unusual dynamics, which we observe in the last quarter century. Realists, though, do not question the phenomenon of "changes" occurring in the world, in reality, whose part they are. However, they do not appreciate power and attractiveness of new ideas, becoming new systems of valuing in foreign policy, new objectives, new approaches to ontological beings, assuming that they are secondary with regard to axioms included in classical paradigms. So if doubts concerning values of function explaining traditional research trends and some nonadherence of positivist methodological approach arise, in particular epistemological measure and traditionally perceived research field, it is justified to ask what can make traditional, positivist research trend attractive or maybe replace it. Question: what purpose such intellectual procedures serve, appears to be not less important.

- Enrichment of knowledge about the world,

- Or about the power of reason,

- Or maybe both purposes. 
"Change" is perceived also as a specific metaphor of transformations occurring in the international system. In this understanding it is closely connected with such notions as "chaos", "stability", "balance", meaning particular phases or stages of its evolution, determined mechanisms and rights valid in each of them. Maybe one can accept, following P. Frankowski, that chaos is "transitional state of system, a crisis, which anticipates emergence of stable forms". It can also symbolise a "state of disorganisation and disorder", though always "anticipating emergence of organised forms, not showing features of randomness" ${ }^{\prime 1}$, that is stabilising the system. Due to that, it is worth to paying greater attention, which the international relations theory does so far, to phases of inequality and chaos in the international system, and make a research field from it, delivering knowledge about how to deal with pathologies causing them.

As it was mentioned before, "change", as a phenomenon permanently inscribed in the international relations may concern many elements; international order, its structure, actors and their attributes, norms and principles valid in the international relations, hierarchy of importance of organisational forms in the international system and importance of determinants of international relations subjects influence, new systems of values or restoring apparently invalid problems the rank of important for dynamic stability of international systems, as well as many other variables. It seems that the most spectacular symbol of changes, which occur in the international system "before our eyes" is clear distancing of representatives of the post-positivist trend, especially constructionism, from material factors exposed by the neorealistic and partly neoliberal trend, influencing the international relations and actors functioning in it for the benefit of ideas, values, special context, historical baggage, etc. This is a change in perceiving the function of science, but also a change expressing distance from clear material determinants of power and position of a participant of the international relations, and by that its possibility of influencing others in order to change their behaviours or changes in the international system, its structure or kinds of interactions..$^{32}$ Let's take the example of Islam, with its fundamental objection against everything that symbolises, distorts or threatens the Muslim conception of life. For researchers of the international relations a challenge becomes a problem of relations between the world of Islam, which rejects the system of values of the Christian world, principles of organisation of secular and religious institutions, materialistic determinism of capitalism and other variables. ${ }^{33}$ How to reconcile idealistic and mythologized

31 Quoting P. Frankowski, Świat pozimnowojenny w świetle teorii chaosu, [in:] Porządek międzynarodowy u progu XXI wieku, (collective work under the edition of R. Kuzniar), Warsaw 2005, p. 543.

32 A. Wendt, Anarchy Is what State Makes of It: the Social Construction of Power Politics, "International Organization" 1992, Vol. 46, No. 2.

${ }^{33}$ More about this topic: Islam a świat, R. Bäcker, S. Kitaba (ed.), Toruń 2004. 
values such as social equality, respecting territorial sovereignty with its distorting justified by fear of terroristic hecatomb? Is a preventive war, built on belief in exceptionality of those, who decide on its utility, an institution that will solve this dilemma? How, in the epoch of "mutual dependence", in which security seems to be available only through cooperation and alliances, to explain the fact, that pursuit of the model of security, whose essence is "relying on oneself"? How to leave the state (so change it) of international relations, which B. Barber describes as a "new, global, anarchic state of nature, in which power and progress rule"? ${ }^{34}$

Moving vectors of change in the international system was generally a domain of politicians a actions, although nowadays a greater and greater role in this neverending process of changes is played by forces so far disregarded or underestimated. They can symbolise disorganisation, unpredictability of behaviours of actors/players in the international relations, disorder, that is an undesirable state from the point of view of politicians and decision-makers, but they can also lead to stability of the international system ${ }^{35}$. The science's task is indicating potential results both for the international systems and its image, and for states, nations, international communities. Because there is always the phase of uncertainty, lack of stability, new rules regulating relations, new authorities behind the "change".

We have to do with the state of international systems symbolising "stability", that is generally desired", when it is "able to keep permanent balance in longer prospect", changes occurring in it allow to maintain this balance. Then we talk about a dynamic balance, because there are no disruptions, which could destroy its equilibrium. ${ }^{36} \mathrm{Bal}-$ ance in the international system and at the same time its structure are determined by the number of countries and distribution of power among them ${ }^{37}$. However, because the international system belongs to the class of dynamic notions, it is difficult to talk about its "absolute stability". We talk rather about a stabilised balance, that is such, when states-actors functioning in it perceive order existing in it as favourable for themselves, both with regard to economy, territory, politics or civilisation, and by their behaviour towards values and rules valid in it to some extent legitimise its shape, structure and kinds of interaction inside the system. Balance, which seems to be obvious, does not stay in opposition to developmental dynamics and changes of the system. It is dynamic as the system, and changes, which occur in its system, have

${ }^{34}$ B.R. Barber, Imperium strachu. Wojna, terroryzm i demokracja, Warszawa 2003, p. 83.

${ }^{35}$ J. Kukułka, Problemy teorii stosunków międzynarodowych, Warsaw 1978, p. 186. See also J. Baylis, E. Cohen, C.S. Gray, J.J. Wirtz, Strategy in the Contemporary World. An Introduction to Strategic Studies, op.cit.

${ }^{36}$ Cz. Mesjasz, op.cit., p. 7.

37 M.A. Kaplan, A Systems Approach to International Politics, [in:] New Approaches to International Relations, M.A. Kaplan (eds.), New York 1968, p. 388. 
a character protecting system against its decline. Actually, the lack of this dynamics of changes is a signal of the beginning of the end of a given international order. So stability of the international system in positive understanding of the notion means its dynamic balance. We describe it as the state of system, in which changes occur in order to maintain their stability. ${ }^{38}$ Such a system, in the opinion of J. Gaddis, has to have "self-regulating" skills, moved under the influence of disruptions coming from the international environment. ${ }^{39}$ Such disruptions may be new social and political claims, but also new ideas, new systems of values, often imposed from the outside, e.g. under the banner of "preventive democracy", placed on twisted logics of American conviction of exceptionality of the United States in the world and their permanent mission of spreading justice and democracy everywhere, where they are not present.

Talking about stability as the state of system, being a consequence of frequently anticipating chaos in the international relations, inequality, randomness, disorder, it is worth paying attention to the fact that not always stability is a synonym of dynamic balance. Stability may also express staticity, determination of petrifying the established social, political, formal-legal orders, lack of progress, disability and reluctance to absorbing changes occurring in the international environment of the system and to making changes in this environment. We have to do with such a situation when regulating and modifying possibilities of the international system are stopped in the way imposed by the method of "manual control".

Generalising, one should state that "change", "chaos" or balance are permanently inscribed in processes occurring in the world, in the system on global level, in bilateral relations, in perception of mechanisms organising international order, guarantee of this and actors changing on the stage of world politics. Due to that reason, it should appear in the centre of interest of international relations theorists. "Change" in this understanding should stay an important element of each correctly constructed analysis of functioning and evolution of the international system, actors of this system, their attributes, etc., dependent and independent variables, both as analytical and practical values, used to examining real systems, existing not only as simulation, parametrical model. ${ }^{40}$ In this understanding it becomes the measure of progress, which generates these changes, similarly like chaos, stabilisation of the system and

${ }^{38}$ System stays in the state of dynamic balance as long as adaptative processes do not threaten its basic objectives and functions. R.H. Lishout calls such a system ultrastable or homostatic, because countries existing in it are able to properly react to temporary disruptions or changes in their environment. More about this topic: R.H. Lishout, Between Anarchy and Hierarchy. A Theory of International Politics and Foreign Policy, Brookfield 1995, p. 117.

${ }^{39}$ Quoting J.E. Dougherty, R.L. Pfaltzgraff Jr., Contending Theories of..., pp. 123-124.

40 See more: Z.J. Pietras, Sztuczna inteligencja w politologii, Lublin 1990. 
predictability of its evolution ${ }^{41}$. Considerations of J.A. Vasquez and R.W. Mansbach included in the theory of long-term global political change ${ }^{42}$ may be interesting and helpful in specifying the notion of change.

\section{SYMBOLS AND CARRIERS OF CHANGES IN THE FIELD OF INTERNATIONAL RELATIONS}

As it was mentioned above, R. Gilpin, when introducing the category of "change" to his researches, situated it as a fundamental element of the international system, its transformations and quality. The carrier of changes in the system and to some extent their symbol are generally states, interested in maintaining its stability, which does not mean staticity. However, nowadays, countries more than other subjects of the international relations are under the pressure of changes in their environment and they are subordinate to this pressure. So they are a subject generating changes, but also an object, which in the course of last fifty years of the twentieth century has been changing the most ${ }^{43}$. As it was mentioned, changes touched the international system. Redistribution of power, which occurs in it, new "players" and new actors, often stronger than states, new rules of behaviours in the international environment symbolise new hierarchy of importance and their new status in the system. Also notional scope of "power" evolves, one of basic analytical categories used in the international relations science, components of real power of states are broadening. A significant carrier and symbol of changes are new actors of the international relations with their rights and expectations of playing new roles in the international relations ${ }^{44}$. As a result of rapid development of multimedia and telecommunication

${ }^{41}$ See more: T. Łoś-Nowak, Stosunki międzynarodowe..., p. 128.

${ }^{42}$ R.W. Mansbach, J.A. Vasquez, The Issue Cycle: Conceptualizing Long-Term Global Political Change, "International Organization" 1983, No. 2, Vol. 37, p. 261.

43 T. Łoś-Nowak, Suwerenność współczesnego państwa: recepcja czy rewizja idei, [in:] Historia. Polityka. Stosunki Międzynarodowe. Jubilee book for 65th anniversary of Prof. Józef Kukułka, Warsaw 1994, p. 297; S. Hoffmann, The Guliver's Troubles, New York 1968, K. Gilarek, Państwo narodowe a globalizacja, Toruń 2002; K.J. Holsti, op.cit.; I. Popiuk-Rysińska, Państwo we współczesnych stosunkach międzynarodowych, Warsaw 1995; K. Trzciński (scientific edition), Państwo we współczesnym świecie, Warsaw 2006.

${ }^{44}$ D.J. Dunn, The Emergence of Change as a Theoretical Concern in International Relations [in:] B. Buzan, R.J. Jons Barry, Change and the Study of International Relations: The Evaded Dimension, London 1981, p. 72; J. Maclean, Marxist Epistemology. Explanations of "Change" in the Study of International Relations, [in:] B. Buzan, R.J. Jons Barry, op.cit., p. 46. 
techniques, there emerges "virtual ethnical society"45 "from the ghetto of isolation". For M.H. Smith, foreign policy is the area of behaviours, in which one can observe changes occurring in the international environment the most clearly. Nevertheless - he emphasises - "their presence, discovering and awareness of the need of change in the foreign policy does not mean that it becomes automatically part of it, or accepted by the international environment" becomes its lasting partner. ${ }^{46} \mathrm{~B}$. Buzan, in turn, pays attention to security, mainly military, as a phenomenon, in which all kinds of changes are the most visible and perceptible. They include strategies of states responsible for security, their hierarchy and importance in the international system, but mainly the structure of international systems and alliances. They cause that "changes in the international system are inevitable" 4 . Changes concern also mechanisms of "global ruling", if hegemony is totally questioned by the international community. ${ }^{48}$

In the post-modern world a state, though, and everything that so far has been demonstrating its exclusiveness in the international system is subordinated to the greatest change. It is also, at the same time, one of the most important stimulators of changes, which occur in it. Interesting with regard to researches would be considering, if cognition of the fact that sovereignty of a post-modern state is subject to significant redefinition, is a right step in the direction of replacing it by regional human community or international community, world civil community ${ }^{49}$. For a researcher of modern integration processes it would be important to catch these

45 D.J. Elkins, Globalization, Telecommunication, and Ethnic Communities, "International Political Science Review" 1997, Vol. 18, No. 2, p. 141.

${ }^{46}$ M.H. Smith, Significant Change and the Foreign Policy Response: Some Analytical and Operational Implications, [in:] B. Buzan, R.J. Barry Jones, op.cit., p. 209. See also: D.J. Dunn, The Emerges of Change as a Theoretical Concern in International Relations, [in:] ibidem, p. 69-83.

47 B. Buzan, Change and Insecurity: A Critique of Strategic Studies, [in:] B. Buzan, R.J. Barry Jones, op.cit., p. 156.

${ }^{48}$ S.D. Krasner, Structural Causes and Regime Consequences, [in:] International Regimes, S.D. Krasner (ed.), New York 1983, p. 2 and next.

49 Such an example can be EU, where everything is subject to the process of changes (borders, European identity, mechanisms of administering), it is in constant process of changes, creating new quality in the international system with result hard to foresee. Surely, next enlargement "will be transforming the Union in an unimaginable way", e.g. for the pattern of neomedieval "Empire”, as J. Zielonka foresees. J. Zielonka, Europa jako Imperium, Warsaw 2007, p.1. 
qualitative changes, critical points, their possible scenarios, indicate what will be e.g. European Union in results of these changes ${ }^{50}$.

In the research process in the international relations science basically the most important is the question, if modern state is the best form of social organisation, or if it may be replaced by other political communities ${ }^{51}$, how much it hampers, how much it reduces or disturbs emancipation of the international community and is the source of social exclusion. If the state is to have future ahead of it, the question what it should be: national or supranational, commercial or military, socially consolidated, culturally integrated or diverse, "empire of good" or "empire of evil", what should distinguish it among other communities, seems interesting.

Another, not less important symbol of changes is the international order, more specifically lack of it or indefiniteness after the decline of two-polar order. In the Westphalia system the strongest states have been carrying construction of the order for over 500 years, they were deciding on its structure, valid norms, mechanisms and institutions of cooperation. They were also anarchising the international system through exposition of their interests, the most often selfish ones. However, if one manages to reject the model of international order built on power, will anarchy in the international system disappear, if we have just entered the phase of global anarchy? Is the international order always guaranteed by states, what if noticeable process of decentralisation of the state's function deepens? When we talk about evolution of perception of the state, we see a territorial state or maybe a more virtual state, in which there is a place for nations, ethnical communities, communities of values or communities of interests. Which of them are carriers of actions joining a territorial state, and which of them a virtual state?

A significant research problem is that development of international community noticed in the post-Westphalia world may generate new a kind of cooperation, new forms of cooperation, but also new conflicts, with harmful consequences for the international order. A problem, to which one should search for answers in analysis of changes in the international order, is discovering new areas of international cooperation, so efficient, that one would be able to provide peace and safety (economic, cultural, military). Which of them are carriers of ideas joining the international system, and which destroy its structure, showing its dark secrets, but also a new, positive face?

${ }_{50}$ See: Instytucjonalizacja wielostronnej wspótpracy międzynarodowej, S. Parzymies and R. Zięba (ed.), Warsaw 2004.

${ }^{51}$ U. Altermatt, Sarajewo ostrzega. Etnonacjonalizm w Europie, Kracow 1998; P. Lawrence, Nacjonalizm. Historia i teoria, Warsaw 2005. 


\section{HOW TO DETERMINE THESE CHANGES AND THEIR RELEVANCE}

In a discussion on symbols and carriers of changes in the field of international relations there are still more arguments and understatements than simple "receipts". Anyway, they are always suspected, especially when they concern fundamental changes for the world. We live in "the most mysterious century in the history of the world, its real nature still stays "dark secret". Demand for "decoders" enabling its discovering is still huge ${ }^{52}$. Maybe the initial point should be identification of factors with destabilisation character, confirming or depreciating conviction of unquestionable position of a state in the international system and the question about a source of evolution of the state and the international system, about the potential of forces ready to change, about the role of human being in globalised world divided for homo sacer and man of success. Also there is an open problem with what methods one should come to "discovering" these changes, which should be treated as really representative for a discipline, which can give an image that is incomplete or "contaminated" by intersubjective experiences, knowledge and way of perceiving examined reality. Today, this is a dilemma far more complex than 20-30 years ago. Today, under the influence of "quick transformation", undergone by the international relations science "from an approach basically solving problems" "to normative analysis of determined communities and possibilities of improving forms of political community" ${ }^{53}$, we have rather to do with a "carnival" of theoretical approaches competing with each other, which does not help in building its image of "serious" science. More and more often one sets also the question, if the international relations science is a "clearly determined domain of intellectual reflection and if it has specific features distinguishing" it on the background of other social sciences. ${ }^{54}$ Regardless of the theoretical assessment of condition of the international relations science and preferences, to which each researcher and observer of the world politics, international relations, game of powers in international systems and other problems in the process of cognition, understanding or interpretation has a right, in order to make research results credible and methodologically correct, a researcher has to have something which we define as methodological awareness, that is clear "confession of faith", that is determining a theory or more broadly a research trend being the basis of its research workshop

${ }^{52}$ S. Rushdie about R. Kapuściński, [in:] W. Bereś, K. Burnetko, R. Kapuściński. Nie ogarniam świata, Warsaw 2007.

${ }^{53}$ Quoting S. Burchill [in:] S. Burchill, R. Devetak, A. Linklater, M. Paterson, Ch. Reus-Smith, J. True, op.cit., p. 18 (from the Introduction).

54 Ibidem, p. 19. 
and, accordingly to this procedure, selection of variables of functioning of the international system and their character, as well as values assigning to them in the process of changes (big/small, important/superficial, short-/long-term). Only with this assumption one can correctly construct models of changes and identify carriers of changes and their value for examined unit. Also determining the character of variables (e.g. dependent and independent, exogenic, endogenic, mixed, others) ${ }^{55}$ is important.

When we talk about the phenomenon of "change" in the international environment, we have to be aware of that they may be changes of quantitative or qualitative character. In researching the change of object qualitative changes are decidedly more important, although accumulation of quantitative changes is the most often a generator of quantitative changes. Also important is determination of the dynamics of changes and their depth. However, an even more important procedure is not so much "registration" of change, but an attempt to answer a question what generates them and where they are located; if it is in the international system, foreign participants in the field of participants of the international relations, in the area of ideas and international norms, culture, system of values and other.

A moderately rational, analytical model of examining the phenomenon of "change" in the international relations, depending on if it concerns international systems, relations between subjects of international relations, their position in the system, quality of international norms, humanitarian issues, should also take into regard such criteria as a way in which they occur, potential costs or losses, which may be brought by their implementation, their validity and importance from the point of view of rights and legitimacy in strategies of subjects of the international relations. As it was emphasised above, also methodologically important is to know who examines changes in the indicated areas and from what theoretical perspective. Such a perspective will be determined by first of all the methodological workshop, not necessarily a verbal declaration. This, what does harm the most not only the science's image, but its results, is theoretical eclecticism in the process of getting to know and understanding the world. In this sense R. Jackson and G. Sørensen are right, when they confess that "Knowledge of theory is essential, because facts do not speak for themselves" ${ }^{56}$, but at the same time one has to accept an argument of those, who claim that "theory follows reality. It anticipates and shapes it", in order to reconstruct it and interpret. ${ }^{57}$

55 See interesting considerations of P. Grudziński, Państwo inteligentne. Polska w poszukiwaniu międzynarodowej roli, Toruń 2008, pp. 23-63.

${ }_{56}$ R. Jackson, G. Sørensen, op.cit., p. 63.

57 R.W. Cox, Towards a Post-hegemonic conceptualization of World Order: Reflections on Relevance of Ibn Khaldun, [in:] J.N. Rosenau, E.O. Czempiel, Governance..., p. 133. 
For example realism, still quite commonly dominating as a research paradigm, is not able to explain many complex problems of modernity or its diagnosis are not convincing enough. A weak explaining element of realism reproached by almost all its shades is the lack of empiricism, possibility of testing set hypotheses. In turn, pluralism with accent on transnational connections, international interdependence, new actors, new carriers of changes seems to better understand the essence and meaning of "change" and that this is the central objective and the subject of researches for them ${ }^{58}$. A pluralist approach provides in this area greater prognostic possibilities, which obviously cannot lead to specific scientific voluntarism, assuming that people can change everything if they only want to, control everything, if they only want to. It is obvious that not everything in the international politics, in behaviours and decisions of a state and other actors of world politics may be explained rationally, by means of notions known in the realistic trend. However, it is not worth rejecting its methodology a limine. It is not easy, using notions typical of it, meanings, functions assigned to them, etc. to explain e.g. the phenomenon of weakening of a state, its decline, and on the other hand intensify again state-building processes in shaped and stable with regard to this Europe (separatist tendencies in Great Britain) or Canada (also), Latin America or unstable Central Africa. How to deal with anarchy of the international system, if we do not answer the question, if it is a product of the state or imposed by the international system, if countries can generally exist without anarchising the system?

If it is a state's product, as constructivists claim, shouldn't one liquidate it? How to reconcile with ideas of rationality and at the same time programme theses of post-postmodernists about emancipation of states and their citizens, depraving influence of the state on life of particular individuals, welfare and social equality in isolation from their material base? Do sovereignty and its different dimensions, power and influence in the international relations generate chaos and instability in the international system? Will there be enough conviction of individuals, that international relations are basically products of human thought, that people are more connected by intersubjective ideas and believes, and that this is a premise to the state that functions better, fairly providing citizens with all goods, that is how? (the same amount for everybody?).

The opinion that people share common ideas, values, history, convictions has not so far set the world free from catastrophes and social inequalities, institutions, about which constructivists write, are still rather the source of contestation and reluctance

${ }^{58}$ J.A. Vasquez, The Post-Positive Debate. Reconstructing..., [in:] R. Viotti and M. . Kauppi, International..., p. 235. 
than a source of allocation of social justice, order, respect for cultural distinctions, etc., more efficient than a state.

One can agree with criticism announced by constructivists concerning the meaning of ideas, values, convictions commonly shared by the international community, only how to explain that besides that crises and wars break out, often with more destructive power than in the past. It is obvious that answers to these questions will sound differently - if we use to explanation the rich Plato's tradition, we will be bewitched by meta-considerations, meta-abstract theoretical constructions of post-postmodernism, and differently if we use Aristotle's tradition, betting on reason and experience.

Made for neorealists, the charge of the lack of awareness of the fact, that the world does not stand in one place, and the task of researchers is examining phenomena and carriers of its change, seems to be, though, formulated a little bit over the top. Such an awareness is possessed by neorealists, with R. Gilpin, who made the category of "change" central point of reference in his dissertation War and Change in World Politics. More significant in the process of cognition and understanding is the question how to unmask these changes, meet them halfway and introduce into the international system, at the same time providing its dynamic character. Surely, realism and neorealism are still able to explain the phenomenon of international conflict better, a territorial state and its permanent presence in the international politics and aspirations of not self-reliant nations (Kurds, Palestinians, recently in the Chechen Republic, Ossetia, Abkhazia) for creating it. However, it disappoints, if it is about diagnoses concerning the future, overestimates hegemony of the strongest countries, as a component of internal order, it is too superficial if it is about researches from the area of international relations, underestimates or does not perceive other change factors than those included in a canon of this paradigm, by which today it seems schematic in theoretical imagination. However, on the other hand "receipts" presented by representatives of the critical school, constructionism or post-modernism regarding e.g. the most important problems of the modern world, such as social inequality and exclusion from international community also disappoint, when it is about their implementation. Critical theory unmasks signs of global domination of rich North over poor South, its representatives "want to set humanity free from oppressive structures of world politics and economy, controlled by hegemonic powers, especially the United States". Postmodernists reject realist assumptions about regularities present in the world politics and international system, about existence of the "objective truth", „...dampen enthusiasm of those, according to whom knowledge may broaden and improve itself, giving people greater and greater power not only over the world of nature, but also over the social world, including the international system". Constructivists, similarly to postmodernists and supporters of critical theory, claim that there does not exist the external, objective social reality as such. The social and political 
world, international system "is not something that exists "somewhere there" like the Solar System. It does not exist on its own, but only as intersubjective awareness between people." ${ }^{59}$ Meanwhile, process of cognition, in order to make results possibly credible and efficient, cannot do without clear notions, qualitatively clear assessing criteria of importance of changes, their results, and first of all a discipline in research, that is remaining consequent in applying the previously accepted criteria, methods and research techniques. Only such an approach may facilitate the process of cognition, understanding, explaining and prospects. It will also allow for analysing these changes and comparing with these, which escape simple "matrix" of realism, today already too static. It helps thinking logically and coherently, but also critically. Ipso facto it helps not only in modelling the world in "our minds", but in changing it or at least indicating directions of changes and their dynamics.

When entering the 21 st century, one has to have the awareness of a need of listening to what representatives of various traditions and schools aiming to broadening the knowledge about the world, understanding its complexity and finding ways allowing for looking more calmly that in stormy period of decline of the Westphalia order, are saying. Not only participants of the international relations and space, in which a researcher operates, the kind of power and world leadership, also mechanisms of management in multi-level and multipolar international order, theway and language of communication change, which causes also that the world of symbols and imaginations about it enhances itself. However, not always cognition and understanding of its complex nature is easier due to that, which does not mean impossible.

59 R. Jackson, G. Sørensen, op.cit., p. 264, 267, 270. 